\title{
PENGEMBANGAN MODEL PEMBELAJARAN ATLETIK NOMOR LOMPAT TINGGI BERBENTUK PERMAINAN UNTUK SISWA SEKOLAH MENEGAH ATAS DI SMA NEREGERI 16 KOTA BANDA ACEH TAHUN PELAJARAN 2019/2020
}

\author{
Indah Lestari $^{(1)}$, Jafaruddin ${ }^{(2)}$ \\ ${ }^{1}$ Pendidikan Jasmani kesehatan dan Rekreasi, Universitas Jabal Ghafur, Kota Sigli \\ ${ }^{2}$ Pendidikan Jasmani kesehatan dan Rekreasi, Universitas Jabal Ghafur, Kota Sigli \\ e-mail: indahlestari@unigha.ac.id, jafaruddin@unigha.ac.id
}

\begin{abstract}
The lack of participation of students in the lesson will decrease the success rate of students in learning, therefore it is necessary an action that is able to involve student participation and at the same time can be used to facilitate students in following the learning process in order to achieve the planned learning goals. thus the teacher must be active in creating an atmosphere so that students are more active in responding to the learning process through the learning model created by the physical education teacher both with the model of defense modification. problem formulation in this study is Creating and developing a high jump number athletic learning model in the form of modified games for high school students at SMA Negeri 16 Kota Banda Aceh in the 2019/2020school year. Based on this, the development of high jump number athletic learning model in the form of games for high school students at SMA Negeri 16 Kota Banda Aceh is presented in the form of demonstration development model, visualization and social simulation in students. The purpose of this research was to develop a high jump number athletic learning model in the form of games for high school students at SMA Negeri 16 Kota Banda Aceh in the 2019/2020school year. The Box Jump Learning Model is included in the first model in the development of the athletic learning model of high jump numbers in the form of games with the correlation between net variables and the third model lies in the vulnerable 0.371. Rope jumping Learning Model is included in the second model in the development of high jump number athletic learning model in the form of games with correlation between clean variables with the third model lies in the vulnerable 0.405 Goal jump learning model included in the third model in the development of athletic learning model high jump number in the form of games with correlation between clean variables with the third model located at rentang 0.205.
\end{abstract}

Keywords: Learning Models, High Jump, Games

\begin{abstract}
ABSTRAK
Kurangnya partisipasi siswa dalam mengikuti pelajaran akan menurunkan tingkat keberhasilan siswa dalam belajar oleh karena itu diperlukan suatu tindakan yang mampu melibatkan partisipasi siswa dan sekaligus dapat digunakan untuk mempermudah siswa dalam mengikuti proses pembelajaran demi tercapainya tujuan pembelajaran yang direncanakan. dengan demikian guru harus aktif dalam menciptakan suasana agar siswa lebih aktif menanggapi proses pembelajaran melalu model pembelajaran yang di buat oleh guru pendidikan jasmani tersebut baik dengan model modifikasi pembelajran.rumusan masalah dalam penelitian ini adalahMembuat dan mengembangkan model pembelajaran atletik nomor lompat tinggi yang berbentuk permainan yang di modifikasi untuk siswa sekolah menegah atas di SMA Negeri 16 Kota Banda Aceh tahun pelajaran 2019/2020. Berdasarkan hal tersebut, maka pengembangan
\end{abstract}


model pembelajaran atletik nomor lompat tinggi yang berbentuk permainan untuk siswa sekolah menegah atas di SMA Negeri 16 Kota Banda Aceh disajikan dalam bentuk model pengembangan demonstrasi, visualisasi dan simulasi sosial pada siswa.Tujuan penelitian ini adalah untuk mengembangkan model pembelajaran atletik nomor lompat tinggi yang berbentuk permainan untuk siswa sekolah menegah atas di SMA Negeri 16 Kota Banda Aceh tahun pelajaran 2019/2020.Model Pembelajaran lompat kotak termasuk dalam model pertama dalam pengembangan model pembelajaran atletik nomor lompat tinggi dalam bentuk permaianan dengan korelasi antar variabel bersih dengan model ketiga terletak pada rentanng 0.371.Model Pembelajaran lompat tali termasuk dalam model ke dua dalam pengembangan model pembelajaran atletik nomor lompat tinggi dalam bentuk permaianan dengan korelasi antar variabel bersih dengan model ketiga terletak pada rentanng 0.405Model Pembelajaran lompat gawang termasuk dalam model ke tiga dalam pengembangan model pembelajaran atletik nomor lompat tinggi dalam bentuk permaianan dengan korelasi antar variabel bersih dengan model ketiga terletak pada rentanng 0.205 .

Kata Kunci: Model Pembelajaran, Lompat Tinggi, Permainan

\section{Pendahuluan}

Banyak faktor yang mempengaruhi rendahnya hasil belajar siswa antara lain kurang kreatifnya guru pendidikan jasmani di sekolah dalam membuat dan mengembangkan media pembelajaran sederhana, guru miskin akan model-model pembelajaran, sehingga dalam proses pembelajaran pendidikan jasmani di sekolah dilaksanakan dalam situasi dan kondisi yang membuat siswa menjadi lebih bosan dalam menangapi pembelajaran yang ada, karena mareka hanya mengejar bangaimana materi pelajaran tersebut dapat selesai tepat waktu, tanpa memikirkan bagaimana pembelajaran itu bermakna dan dapat diaplikasikan oleh siswa dalam kesehariannya.

Sekolah merupakan suatu lembaga yang berperan dalam mengembangkan cabang olahraga atletik, khususnya nomor lompat tinggi. Dalam hal ini Depdikbud (1994:13) menjelaskan bahwa: "siswa yang berada pada tingkat sekolah menengah wajib mendapatkan pengajaran olahraga dan kesehatan. Dari sekian banyak cabang olahraga yang di ajarkan disekolah, kali ini penulis ingin mengkaji sedikit dari cabang olahraga atletik.Nomor-nomor atletik yang di programkan dalam proses belajar mengajar di tingkat sekolah menegah atas (SMA) adalah nomor lari, lompat dan lempar. Nomor lompat di bagi lagi menjadi lompat jauh dan lompat tinggi.Pengajaran nomor lompat meliputi teori lompat, macam-macam teknik lompat dan praktek latihan teknik lompat.

Dilain pihak hasil pengamatan di SMA Negeri 16 Kota Banda Aceh, menunjukan proses pembelajaran pada materi lompat tinggi belum melibatkan siswa secara aktif dalam kegiatan belajar dan pembelajaran. Proses belajar mengajar hanya didominasi oleh beberapa siswa saja, hal ini menunjukan kurang efektifnya suatu metode dalam proses belajar dan pembelajaran yang diterapkan oleh guru dan kurangnya tingkat partisipasi siswa dalam proses pembelajaran. Akibatnya hanya sebagian siswa saja yang secara aktif mengikuti preses pembelajaran, sedangkan beberapa siswa masih asyik bercanda, ngobrol dengan teman, atau bermain sendiri dilapangan tanpa menghiraukan apa yang dijelaskan oleh guru. Kurangnya partisipasi siswa dalam mengikuti pelajaran akan menurunkan tingkat keberhasilan siswa dalam belajar oleh karena itu diperlukan suatu tindakan yang mampu melibatkan partisipasi siswa dan sekaligus dapat digunakan untuk mempermudah siswa dalam mengikuti proses pembelajaran demi tercapainya tujuan pembelajaran yang direncanakan. dengan demikian guru harus aktif dalam menciptakan suasana agar siswa lebih aktif menanggapi proses pembelajaran 
melalu model pembelajaran yang di buat oleh guru pendidikan jasmani tersebut baik dengan model modifikasi pembelajran.

Bertitik tolak dari permasalahan di atas maka perlu adanya tindakan lebih lanjut dari pihak sekolah maupun guru pendidikan jasmani untuk kedepannya menerapkan sistem didalam pembelajaran agar pada saat proses pembelajaran yang disampaikan materi dan manfaat dari pembelajaran itu pun dapat tersalurkan dengan baik kepada setiap siswa. Oleh karena itu perlu adanya pengembangan model pembelajaran lebih lanjut pada sistem pembelajaran yang ada disekolah tersebut.

Berdasarkan pokok masalah yang telah penulis uraikan, maka penulis ingin melakukan penelitian yang berhubungan dengan bagaimana cara agar siswa SMA Negeri 16 Kota Banda Aceh menjadi lebih efektif dan guru dapat mengembangkan model pembelajaran terhadap pembelajaran jasmani di sekolah. Jadi penulis menetapkan judul "Pengembangan Model Pembelajaran Atletik Nomor Lompat Tinggi Berbentuk Permainan untuk Siswa Sekolah Menegah Atas Di SMA Negeri 16 Kota Banda Aceh Tahun Pelajaran 2019/2020".

Berdasarkan dari latar belakang diatas, maka yang menjadi tujuan penelitian ini adalah: Untuk mengembangkan model pembelajaran atletik nomor lompat tinggi yang berbentuk permainan untuk siswa sekolah menegah atas di SMA Negeri 16 Kota Banda Aceh tahun pelajaran 2019/2020.

\section{Metode}

Adapun teknik pengumpulan data dalam penelitian ini menggunakan wawancara, observasi dan angket.

Wawancara pada penelitian ini dilakukan pada guru Penjas dan siswa kelas XI Sekolah Menengah Atas SMA Negeri 16 Kota Banda Aceh.

Observasi yang dilakukan dalam penelitian ini adalah peneliti mengamati proses pembelajaran Penjasorkes pada
Sekolah Menengah Atas SMA Negeri 16 Kota Banda Aceh

Kuesioner yang digunakan harus membuat butir-butir yang sifatnya spesifik dan luas pemahamannya serta dapat diaplikasikan sesuai dengan kondisi pembelajaran pada Sekolah Menengah Atas SMA Negeri 16 Kota Banda Aceh. Kuesioner yang diberikan adalah kepada siswa kelas XI Sekolah Menengah Atas SMA Negeri 16 Kota Banda Aceh

Dalam teknik pengumpulan data, triangulasi diartikan sebagai teknik pengumpulan data yang bersifat menggabungkan dari berbagai teknik pengumpulan data dan sumber data yang telah ada (Sugiyono,2012:241).

Pengumpulan data dilapangan memiliki jumlah yang sangat banyak, maka perlu adanya perincian yang baik.Dengan demikian, diperlukan analisis data dengan menggunakan teknik reduksi data. Dengan adanya reduksi data, maka nantinya akan memberikan gambaran yang lebih jelas kepada peneliti sehingga peneliti mudah dalam melakukan pengumpulan data.

Setelah data penelitian dilakukan dengan teknik reduksi data, maka selanjutnya dilakukan penyajian data.Dalam penelitian kalitatif ini, penyajian data yang dilakukan bisa dalam bentuk uraian, hubungan antar kategori dan bagan.

Teknik verification dilakukan dengan menyimpulkan data yang telah didapat melalui reduksi data, penyajian data, setelah itu baru di simpulkan. Apabila kesimpulan awal yang dilakukan pada penelitian tidak ditemukan bukti dalam pengumpulan data, maka kesimpulannya akan berubah. Begitu juga sebaliknya.

\section{Hasil dan Pembahasan}

Tampak dimensi dalam skala model pembelajaran atletik nomor lompat tinggi berbentuk permaianan untuk Siswa Menengah atas Negeri 16 Kota Banda Aceh atletik nomor lompat tinggi berbentuk permaianan untuk siswa menengah atas 
Jurnal Sosial Humaniora Sigli (JSH)

p ISSN : 2615-3688

$e$ ISSN : 2716-0270

http://journal.unigha.ac.id/index.php/JSH

negeri 16 Kota Banda Aceh saling berkorelasi satu sama lain, walaupun secara analisis masing-masing model pembelajaran atletik nomor lompat tinggi berbentuk permaiann untuk siswa menengah atas negeri 16 Kota Banda Aceh faktor corelation matrix dapat dilihat pada Tabel

Tabel 1. Hasil Correlation Matrix

\begin{tabular}{|l|r|r|r|}
\hline $\begin{array}{c}\text { Model } \\
\text { Pembelajaran }\end{array}$ & \multicolumn{1}{c|}{$\begin{array}{c}\text { Lompat } \\
\text { Kotak }\end{array}$} & \multicolumn{1}{c|}{$\begin{array}{c}\text { Lompat } \\
\text { Tali }\end{array}$} & $\begin{array}{c}\text { Lompat } \\
\text { Gawang }\end{array}$ \\
\hline Lompat Kotak & 1,000 &,- 748 &, 003 \\
Lompat Tali &,- 748 & 1,000 &, 415 \\
$\begin{array}{l}\text { Lompat } \\
\text { Gawang }\end{array}$ &, 003 &, 415 & 1,000 \\
\hline
\end{tabular}

Berdasarkan hasil analis faktor model pembelajaran di atas, maka dapat dilihat faktor dalam model pembelajaran atletik nomor lompat tinggi berbentuk permainan untuk siswa menengah atas di SMAN 16 Kota Banda Aceh, merupakan faktor yang saling berkorelasi dengan rentang 0.003 sampai 0.078, tampak skala model pembelajaran atletik lompat tinggi yang dikembangkan merupakan instrumen yang bersifat multidimensional.

Model pembelajaran lompat gawang adalah model ketiga dalam pengembangan pembelajaran lompat tinggi dengan korelasi antara variabel bersih dengan model pertama yang paling besar terletak pada rentang 0.693 sampai 0.971 , lebih jelasnya dapat dilihat pada lampiran

Model pembelajaran lompat tali adalah model kedua dalam pengembangan pembelajaran lompat tinggi dengan korelasi antara variabel bersih dengan model pertama yang paling besar terletak pada rentang 0.610 sampai 0.924 , lebih jelasnya dapat dilihat pada lampiran

Model pembelajaran lompat kotak adalah model pertama dalam pengembangan pembelajaran lompat tinggi dengan korelasi antara variabel bersih dengan model pertama yang paling besar terletak pada rentang.0.945 sampai 0.982 lebih jelasnya dapat dilihat pada lampiran

Proses pengembangan model pembelajaran atletik nomor lompat tinggi berbentuk permainan untuk Sekolah Menengah Atas Negeri 16 Kota Banda Aceh......... setelah tiga tahapan tersebut selesai maka akan dapat instrumen model pembelajaran lompat tinggi berbentuk permainan untuk Siswa Menengah Atas yang akan dikembangkan dan diujicoba, kemudian hasil dianalisis dengan pengujian validitas, reliabilitas dan analisi faktor.

Berdasarkan hasil pengujian data pada bab hasil penelitian, dalam tiga bentuk model permainan pembelajaran atletik lompat tinggi nomor lompat tingg terdiri dari 20 item ditiap-tiap model yang bila di gabung maka berjumlah 60 item, maka dari 60 item dari tiga model pembelajaran ternyata memiliki tingkat validitas yang sangat tinggi dengan skor 0,982 hal ini mengacu pada kriteria yang dikemukan oleh Morehouse, Stull dan Bergemen dalam Sugiyono, (2012:172-173) bahwa 000- \pm . 200 derajat validitas sangat rendah, 200- \pm 400 derajat validitas rendah, $400 \pm 600$ validitas sedang, $600 \pm 800$ derajat validitas tinggi dan $800 \pm 1000$ derajat validitas sangat tinggi, disamping itu juga diperoleh nilai validitas, item yang memiliki tingkat validitas paling kecil adalah item intrrumen no 10 yaitu, 0,610 terdapat pada model pembelajaran lompat tali dalam model pembelajaran atletik nomor lompat tinggi berbentuk permainan sedangkan item yang tingkat validitas paling besar terdapat pada item instrumen no 19 yaitu 0,982 terdapat pada model pembelajaran lompat kota dalam model pembelajaran atletik nomor lompat tinggi. Ketiga model pembelajaran atletik nomor lompat tinggi berbentuk permaianan untuk siswa menengah atas di SMAN 16 Kota Banda Aceh memiliki tingkat validitas tinggi.

Secara keseluruhan model pembelajaran atletik nomor lompat tinggi berbentuk permainan pada SMA Negeri 16 
Kota Banda Aceh yang terbagi dalam tiga model pembelajaran mimiliki tingkat validitas sangat tinggi serta tinggkat reliabilitas sangat tinggi yang dapat dijadikan salah satu model pembelajaran lompat tinggi pada siswa Sekolah Menengah Atas yang ada di Banda Aceh khususnya dan Provinsi Aceh umumnya. Rentang validitas yang sedang serta memiliki tingkat reliabilitas yang sangat tinggi dianggap wajar, karena proses tahapan pengembangan model pembelajaran ini benar-benar dilakukan dengan melibatkan pakar pendidikan jasmani langsung. Hasil persentase sumbangan konstruk model pembelajaran lompat tinggi, yaitu $20 \%$ di model lompat kotak, $20 \%$ di model lompat tali dan $20 \%$ dimodel lompat gawang.

Berdasarkan hasil Uji anti-image Matrices atau anti image Corelation dianalisis untuk menentukan variabel atau dimensi mana yang layak digunakan dalam analisis lanjutan. Adapun hasil anti- image corelation ternyata dari tiga model yang masing-masing model yaitu 1) model pembelajaran lompat kotak terdiri dari 20 item instrumen, 2) model pembelajaran lompat tali terdiri dari 20 item instrumen, 3) model pembelajaran lompat gawang terdiri dari dari 20 item instrumen.

\section{Simpulan dan Saran}

Model Pembelajaran lompat kotak termasuk dalam model pertama dalam pengembangan model pembelajaran atletik nomor lompat tinggi dalam bentuk permaianan dengan korelasi antar variabel bersih dengan model ketiga terletak pada rentanng 0.371 .

Model Pembelajaran lompat tali termasuk dalam model ke dua dalam pengembangan model pembelajaran atletik nomor lompat tinggi dalam bentuk permaianan dengan korelasi antar variabel bersih dengan model ketiga terletak pada rentanng 0.405

Model Pembelajaran lompat gawang termasuk dalam model ke tiga dalam pengembangan model pembelajaran atletik nomor lompat tinggi dalam bentuk permaianan dengan korelasi antar variabel bersih dengan model ketiga terletak pada rentang 0.205

Berdasarkan hasil reduksi, pengujian validitas, pengujian reliabilitas dan analisis faktor, maka penulis menyimpulkan dari tiga model pembelajaran yang terdiri dari 20 item di tiap-tiap model dapat diikutsertakan dalam model pembelajaran atletik nomor lompat tinggi karena memiliki tingkat kesahihan yang tingggi dan tingkat keterandalan yang tinggi. Mengingat kebutuhan yang jelas dalam multi dimensi dari satu alat pegembangan model pembelajaran lompat tinggi, model pengembangan lompat tinggi berbentuk permainan untuk siswa sekolah menengah atas di rancang berdasarkan dari tiga model pembelajaran yaitu model pembelajaran lompat kotak, model pembelajaran lompat tali, model pembelajaran lompat gawang.

\section{Daftar Pustaka}

Amir, Nyak.(2006). Pembelajaran Pendidikan Jasmani. Banda Aceh: Syiah Kuala University Press.

Arikunto, S. (1991).Prosedur Penelitian Suatu Pendekatan Praktis. Jakarta: PT. Bina Aksara.

Departemen P\& K, (1984).Pelajaran Bahasa Indonesia.Pendidiakan Luar Sekolah Direktur Jenderal Pendidikan Dasar dan Menengah.

Effendi, Hasyim. 1983. Fisiologi Kerja Dan Olahraga, Peranan Tes Kerja Untuk Diagnostik. Bandung: Alumni.

Tim Penjaskes, (2002). Pendidikan Jasmani dan Kesehatan SLTP Kleas 1. Jakarta: Yudistiran.

Sugiyono, (2012).Metode Penelitian Kuantitatif Kualitatif dan $R \& D$. Bandung: ALFABETA.

Supriadi, D. (1998). Mengangkat Citra dan Martabat Guru. Yogyakarta: Adicita Karya Nusantara. 